\title{
A Blended Learning Module on the Writing Academic Purpose Course (A Research and Development Approach)
}

\author{
Eny Maulita Purnama Sari \\ English Department, Universitas Nahdlatul Ulama Lampung, Indonesia \\ Jl. Lintas Timur, Mataram Marga, East Lampung \\ ennymaulita42@gmail.com
}

\author{
Nurul Aini \\ English Department, Universitas Nahdlatul Ulama Lampung, Indonesia \\ Jl. Lintas Timur, MataramMarga, East Lampung \\ aininuru192@gmail.com
}

\begin{abstract}
This study aimed to determine the effectiveness of the module based on blended learning model in "Writing Academic Purpose" course, to evaluate the validity of the module based on the assessment by the Context, linguists and media experts used validation sheets. The module was developed using Research and Development Approach (R\&D). the outputs of this research was an blended learning module of "Writing Academic Purpose". The module was implemented using the e-learning system of UNU Lampung. The subject of this research was the blended learning module that implemented to the English Department students. The object of the research were the content of the module. The module is declared valid from the validation by validators, the module could improve the students' reasoning and creativity, the module's effectiveness is achieved in this study.
\end{abstract}

Keywords: Blended learning; Module; elearning system

\section{INTRODUCTION}

E-learning has become an increasingly important part of the teaching and learning experience for lecturers and also for students. Virtual classroom learning makes it possible to overcome the difficulties and limitations posed by traditional classroom learning. This technology enables various sources to establish a global network of resources and provide information sharing for education.

The design and preparation of lecture modules based on blended learning requires consideration including the selection of topic topics. Material delivered online is material that can produce student creativity in writing that presents information and requires considerable time when delivered face-to-face, has links to the environment and everyday life (Sadiman, 2010). 
IJOLT TL, Vol. 4, No. 3, September 2019

p ISSN: 2502 2326; e ISSN: 2502 8278

Https://soloclcs.org; Email: ijolt1@gmail.com

Center of Language and Cultural Studies, Surakarta, Indonesia

Sari, Purnama Maulita Eny \& Aini, Nurul. 2019. A Blended Learning Module on

the Writing Academic Purposes Course(A Research and Development Approach).

IJOTL TL (2019), 4(3): 173 186. DOI: 10.30957/ijot-ltl.v4i3.608.

Based on a survey on Blended learning conducted by Kim and Bonk (2006) within 10 years, the use of online learning has increased the interest of students detected in the 10th year (2013), almost $100 \%$ of students participated in blended learning activities conducted by their instructors.

Other research on blended learning (Rahmana, 2015; Wijayanti, Maharta \& Suaa, 2017; Syarif, 2012) although they have examined the effectiveness of blended learning and learning modules based on blended learning, this research has described the effectiveness of the learning process using modules based on blended learning in language major students, especially English. Most blended learning research is studied in applied science studies. So this research is expected to be able to improve the skills, reasoning and creativity of students majoring in English in the subject "Writing for Academic Purpose". Because there were many students are able to understand the language, but most students face the problem of communicating their ideas effectively. The problem is that students do not have much vocabulary and lack creativity in writing. Therefore, many institutions exert their efforts to learn English (Mourtaga, 2010). A mission that is difficult to fulfill by a teacher / lecturer is to teach English creatively, so that students can become independent learners and benefit from the innovative teaching techniques adopted by the lecturer.

\section{REVIEW OF LITERATURE}

\subsection{Blended Learning Module}

According to Prastowo (2011:106) the module is a teaching material that is arranged systematically in a language that is easily understood by students according to their level of knowledge and age, so that they can learn on their own (independently) with minimal help or guidance from educators. The module to be developed must be in accordance with the module framework. The module framework according to Daryanto (2013:25) consists of 1) preface, 2) table of contents, 3) module position map, 4) glossary, 5) introduction consisting of competency standards and basic competencies, description, time, prerequisites, module usage instructions, final objectives and competency standard mastery checks, 6) learning consisting of objectives, material descriptions, summaries, assignments, tests, worksheets and practice, 7) evaluations consisting of cognitive tests, psychomotor tests, and attitude assessments, 8) answer key, and 9) Bibliography.

In the blended learning method Mosa (2006) said that what is mixed in the learning method are the two main elements, namely learning in class with conventional face-to-face (classroom lesson) with learning online. Learning methods are carried out in classroom lessons and online both independently and collaboratively, using the infrastructure of information and communication technology (the Internet). 


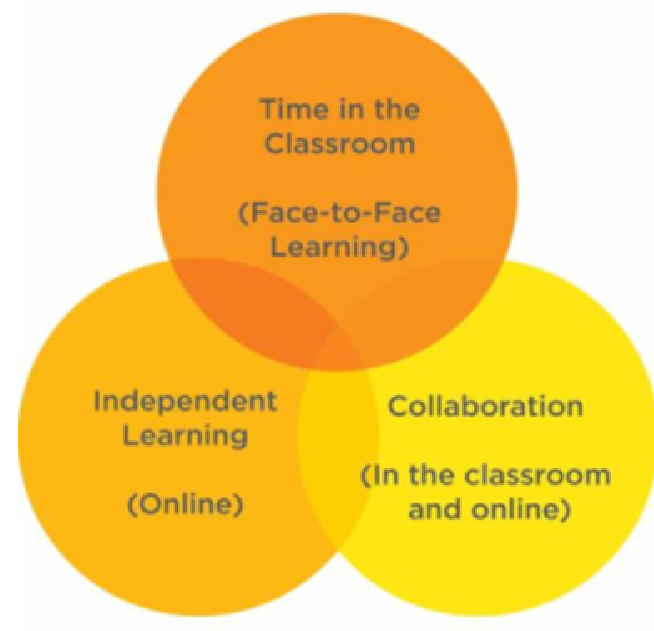

Figure 2.1. Blanded Learing Concept

Blended learning based learning is carried out in three learning concepts, namely (1) Time in the Classroom, where learning is traditionally done face to face, (2) Independent Learning, students learn independently through the internet to get teaching materials delivered by the teacher, (3) Collaboration, learning is done by combining traditional classes and Independent Learning classes.

Based on this description, it can be concluded that the Blended Learning-based Module that will be developed is a module that is arranged systematically in a language that is easily understood by students and contains Blended Learning features, namely Face to face Learning, Independent Learning, and Collaboration.

\subsection{Blended Learning for Higher Education}

Integrated learning must be accompanied by an awareness of the possibilities of flexible learning designs and challenges. Blended learning must be accompanied by a good understanding of the tertiary education environment, communication characteristics, disciplinary needs and human resources. The design of blended learning is expected to be able to change and restructure the teaching and learning process fundamentally.

Higher education must provide learning experiences for students that involve community needs in the 21 st Century. Swail (2002) with changing rules, there will be increased pressure on a tertiary institution to evolve, adapt or stop. Drucker (1999), selfevaluation in learning is needed to improve the quality of the learning system in high education. Blended learning is one of the learning models that can be used in tertiary institutions. Where students were active and they did the assessment their self.

Blended learning triggers students to be independent in the learning process. In the learning process of students, controlled self-regulated learnig (SRL) will facilitate students in achieving their academic goals. According to Zimmerman (1989) in 
IJOLT TL, Vol. 4, No. 3, September 2019

p ISSN: 2502 2326; e ISSN: 2502 8278

Https://soloclcs.org; Email: ijolt1@gmail.com

Center of Language and Cultural Studies, Surakarta, Indonesia

Sari, Purnama Maulita Eny \& Aini, Nurul. 2019. A Blended Learning Module on

the Writing Academic Purposes Course(A Research and Development Approach).

IJOTL TL (2019), 4(3): 173 186. DOI: 10.30957/ijot-ltl.v4i3.608.

Sudarman (2014), SRL consists of three aspects of learning, namely cognition, motivation, and behavior. The ability of SRL will place students in the process of responsibility in learning so that students will better understand the concepts and relationships or explanations of a lecture material. So that students can construct their own lectures and solutions, and do not depend on the lecturer, but they motivate themselves and develop learning strategies independently.

\subsection{Writing for Academic Purpose}

Writing for academic purpose courses are delivered to students of English language education at UNU Lampung with the aim of giving students an understanding oriented to academic theory and practice, especially in essay writing.

Writing for academic purpose is a compulsory subject at UNU Lampung for PBI students. This course teaches students to write academically, in accordance with academic writing guidelines. The main topics in the Constitutional Court are the characteristics of academic writing, academic writing formats (conventional and postmodernism), the right way to write statements, paragraphs, use of modalities in statements, quotes and use of passive and active language in academic writing.

\section{METHODS}

\subsection{Research Design}

In connection with the objectives of this study, researchers adopted Research and Development (R\&D) by Borg and Gall (in Sugiono, 2007:408). Research and Development (R\&D) is a process used to develop and validate educational products. In accordance with the educational context, $R \& D$ develops learning products related to curriculum, syllabus, and learning material (Aini, 2016). The author uses R\&D to develop modules with a blended learning model.

Borg and Gall (in Sugiono, 2007:408) suggest three steps called introduction, development and validation. Further explanation can be seen in the following figures:

\section{Figure 2. Research Procedures in developing Modules Using Blended Learning}
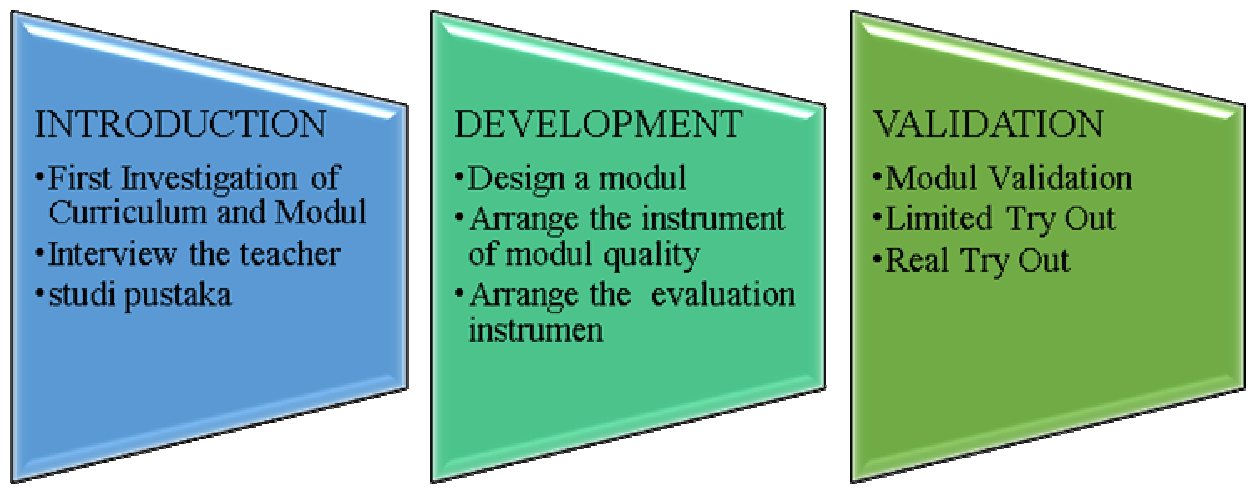
IJOLT-TL, Vol. 4, No. 3, September 2019

p ISSN: 2502 2326; e ISSN: 2502 8278

Https://soloclcs.org; Email: ijolt1@gmail.com

Center of Language and Cultural Studies, Surakarta, Indonesia

Sari, Purnama Maulita Eny \& Aini, Nurul. 2019. A Blended Learning Module on

the Writing Academic Purposes Course(A Research and Development Approach).

IJOTL TL (2019), 4(3): 173 186. DOI: 10.30957/ijot-ltl.v4i3.608.

Based on figure 2, the entire research activity consists of three stages, namely introduction, development, and validation. The whole stage is an inseparable process in module development.

\subsection{Research Settings and Subjects}

The research was conducted in March - June 2019. The research settings were carried out at UNU Lampung using the UNU Lampung e-learning system with research subjects of 5 lecturers and English linguists as well as 10 semester VI PBI students.

\subsection{Research and Development Procedure}

Overall development research activities are carried out in three stages, namely: preliminary, product development and test stages. These three stages are an inseparable part of a development process. The details are explained in the following description:

\section{Preliminary}

Phase The preliminary stage includes an initial investigation or analysis of the curriculum and identification of the modules used, as well as a literature study that aims to gather information and references. This stage promotes performance analysis that includes student background and needs analysis including problem solving analysis, determining relevant material, effective learning strategies, and conditions of learners and learning.

\section{Design and Development}

Phase, namely module design, preparation of module assessment instruments, and preparation of evaluation instruments. At the module design stage the learning objectives are determined. Next, find the module and answer key. At this stage, the development designs a learning model based on blended learning in such a way as formulating learning objectives that can be used online and offline. Furthermore, the development is carried out by developing items of questions to measure the level of achievement of objectives. Basically, learning based on blended learning takes into consideration the use of learning strategies because they have to be in accordance with student interests. Therefore, researchers modify the learning model through the use of the web, blogs, power points, SOPs, and games on learning writing for academic purposes based on blended learning on e-learning systems.

\section{Product Testing}

Phase is carried out in three ways, namely material validation, limited trials, and field trials. These three stages are mutually sustainable to assess the quality of the module, test the level of completeness and readability of the module and conduct direct trials. 
IJOLT TL, Vol. 4, No. 3, September 2019

p ISSN: 2502 2326; e ISSN: 2502 8278

Https://soloclcs.org; Email: ijolt1@gmail.com

Center of Language and Cultural Studies, Surakarta, Indonesia

Sari, Purnama Maulita Eny \& Aini, Nurul. 2019. A Blended Learning Module on

the Writing Academic Purposes Course(A Research and Development Approach).

IJOTL TL (2019), 4(3): 173 186. DOI: 10.30957/ijot-ltl.v4i3.608.

\subsection{Data Analysis Techniques}

Analysis in this research, includes data analysis on the development of Blended Learning-based modules, the quality of Blended Learning-based modules based on validity assessment and the effectiveness of using Blended Learning-based modules.

1. Module Development Based on Blended Learning

On data regarding the development of Blended Learning module based on the module assessment sheet.

2. Module Quality Based on Blended Learning Based on Validator Assessment

Data on module quality based on Blended Learning is obtained with a module assessment sheet of research subjects and the results of the validator. On the assessment module sheet the data obtained is then analyzed descriptively by calculating averages and determining their categories.

\section{Effectiveness of Using Blended Learning Modules Based on Blended Learning}

Module effectiveness data is obtained from pre-test and post-test. The test instrument for the use of a blended learning system is given before and after treatment (using modules). Furthermore, the data is analyzed using descriptive statistical analysis using t-test to see the effectiveness of the blended learning-based modules.

\subsection{The ADDIE Model}

The interest in using ADDIE models in learning aims to facilitate data analysis in research and development of learning modules. ADDIE stands for Analysis Design Development Implementation and Evaluation. ADDIE can be used as an effective, dynamic and supportive learning development model. Historically, ADDIE emerged in the 1990s by Raiser and Mollendra. There are several stages in using this model, namely:

\section{Analyze (Analysis)}

Conducted by analyzing learners (attributes, needs, and karakeristik), cost, delivery alternatives, limitations, time of learning, and targeted performance (Powers, 1997).

\section{Design (Design)}

Learning with the blended learning method is done online and offline in order to develop the cognitive abilities of learners in accordance with the learning objectives (Driscoll, 1998:50). In this stage, the objectives, indicators, layout, and taste values of the program, guidelines, lessons, and module itself are determined (Hall, 1997:231). It also designed the content of learning with electronic/ internet intermediaries (Porter, 1997:127).

\section{Develop (Development)}


IJOLT TL, Vol. 4, No. 3, September 2019

p ISSN: 2502 2326; e ISSN: 2502 8278

Https://soloclcs.org; Email: ijolt1@gmail.com

Center of Language and Cultural Studies, Surakarta, Indonesia

Sari, Purnama Maulita Eny \& Aini, Nurul. 2019. A Blended Learning Module on

the Writing Academic Purposes Course(A Research and Development Approach).

IJOTL TL (2019), 4(3): 173 186. DOI: 10.30957/ijot-ltl.v4i3.608.

At this stage carried out by preparing and providing all the media needed, the benefits of the internet to present various forms of media so that in accordance with the characteristics of the learner (Learner, 1997:196). Determine the types of interactions that motivate active, creative, innovative and highly motivated learners (Porter, 1997:200).

\section{Implement (Implementation)}

At this stage the researchers uploading the module on e-learning system, duplicate and distribute to students module and set up additional alternative learning online through google classes if technical errors (Simonson et al, 2000:115).

5. Evaluate (Evaluation)

Performed at this stage, namely pre-test or limited trial module, expert validation, and post-test or field trial.

\section{RESULTS AND DISCUSSION}

At the preliminary study stage consists of analysis of course descriptions and the Writing for Academic Purpose syllabus. The explanation is as follows:

a) Course Description of Writing for Academic Purpose

This subject studies the Theory of academic writing and Practice of academic writing. Writing for Academic Purpose courses can be seen in table 1 below:

\section{Table 1. Course Description}

This subject is a study of theory and practice of academic writing. Topics include: characteristics of academic writing, formats of academic writing (conventional and postmodernism), appropriate ways to write statements, paragraphs, the use of modality in statements, citing and referencing, the use of passive and active voice and "I" in academic writing and the concept of "writing up" in writing a position essay.

b) Identification of the Structure of Teaching Material

Based on the analysis of the description and syllabus of the "Writing for Academic Purpose" course, it can be defined the structure of the material module of "Writing for Academic Purpose"as follows:

\section{Table 2. Course Topic}

\begin{tabular}{lll}
\hline Main Topic & \multicolumn{1}{c|}{ Section } \\
\hline Introduction to academic & 1. & Definition of academic writing \\
writing & 2. & Structure of academic writing \\
& 3. & Essay and its pattern \\
\hline
\end{tabular}


IJOLT TL, Vol. 4, No. 3, September 2019

p ISSN: 2502 2326; e ISSN: 2502 8278

Https://soloclcs.org; Email: ijolt1@gmail.com

Center of Language and Cultural Studies, Surakarta, Indonesia

Sari, Purnama Maulita Eny \& Aini, Nurul. 2019. A Blended Learning Module on

the Writing Academic Purposes Course(A Research and Development Approach).

IJOTL TL (2019), 4(3): 173 186. DOI: 10.30957/ijot-ltl.v4i3.608.

Characteristics of academic writing
1. Kinds of Characteristics of academic writing

2. Implementation of kinds of characteristics of academic writing

1. Types of academic writing

2. Example of academic writing

(conventional and

postmodernism)

Appropriate ways of writing statements (distancing devices, passive and active voice, the use of "I")

Summarizing (convention and explanation)

Summarizing (exercises)

Paraphrasing (convention and explanation)

Paraphrasing (practice)

The use of modality in statements (convention and explanation)

Making statements (exercises)

Structure of academic texts (convention and explanation)

Getting to know more on academic texts (Analysis of academic texts)

Getting to know more on academic texts (Analysis of academic texts)
1. The rules of academic writing

2. The pattern of academic writing
1. Theory of summarizing

2. The rule of summarizing

3. Example and practice summarizing

1. Theory of paraphrasing

2. The rule of paraphrasing

3. Example and practice paraphrasing

1. Theory of Verb

2. The use of modality

3. Practice

1. Types of genre

2. Structure of academic writing

1. Discourse analysis

2. The way of discourse analysis 
IJOLT TL, Vol. 4, No. 3, September 2019

p ISSN: 2502 2326; e ISSN: 2502 8278

Https://soloclcs.org; Email: ijolt1@gmail.com

Center of Language and Cultural Studies, Surakarta, Indonesia

Sari, Purnama Maulita Eny \& Aini, Nurul. 2019. A Blended Learning Module on

the Writing Academic Purposes Course(A Research and Development Approach).

IJOTL TL (2019), 4(3): 173 186. DOI: 10.30957/ijot-ltl.v4i3.608.

\begin{tabular}{lll}
$\begin{array}{l}\text { Writing a position essay } \\
\text { (drafting) }\end{array}$ & 1. & $\begin{array}{l}\text { Outline of Essays } \\
\text { Practice }\end{array}$ \\
\hline $\begin{array}{l}\text { Writing a position essay } \\
\text { (revising) }\end{array}$ & 1. & $\begin{array}{l}\text { Analyze the Essay } \\
\text { Revise the Essay }\end{array}$ \\
\hline $\begin{array}{l}\text { Writing a position essay } \\
\text { (final) }\end{array}$ & 1. & Result of Essay \\
\hline
\end{tabular}

The topic structure of the teaching material "Writing for Academic Purpose" shown in the table above is used to develop teaching materials "Writing for Academic Purpose" based on blended learning.

\subsection{Development Phase}

In the development phase of this module, the implementer of activities carried out several activities, namely the preparation of draft modules, expert review, revised module modules.

a) Results of Drafting Teaching Material

Draft of "Writing for Academic Purpose based on blended learning" modules were arranged according to the structure of the "Writing for Academic Purpose module based on blended learning" in table 2 . The draft module is prepared with a systematic cover page, introductory page, introductory content page, student activity sheet, exercises problems, and bibliography. The draft module is validated and reviewed by material, language, English, media and technology experts. The results of the validation assessment are used as a reference to the module revision that will be tested on students.

b) Results of Expert Assessments

After the module has been prepared, the next step is validated by 5 experts. Validation is done by filling out the validation sheet of teaching materials (assessment instruments). Analysis of the validation results is presented in the following table 3:

Table 3. Validation of the blended learning module

\begin{tabular}{ccccc}
\hline No & $\begin{array}{c}\text { Module Validation } \\
\text { Aspect }\end{array}$ & $\begin{array}{c}\text { Number of } \\
\text { Aspects }\end{array}$ & Average & Category \\
\hline 1 & Content Feasibility & 9 & 32.33 & Good \\
\hline 2 & Presentation Feasibility & 13 & 46 & Good \\
\hline 3 & Language Feasibility & 4 & 13.5 & Good \\
\hline & Total & $\mathbf{2 6}$ & $\mathbf{9 1 . 8 3}$ & Good \\
\hline
\end{tabular}


IJOLT $\sim$ TL, Vol. 4, No. 3, September 2019

p ISSN: 2502 2326; e ISSN: 2502 8278

Https://soloclcs.org; Email: ijolt1@gmail.com

Center of Language and Cultural Studies, Surakarta, Indonesia

Sari, Purnama Maulita Eny \& Aini, Nurul. 2019. A Blended Learning Module on

the Writing Academic Purposes Course(A Research and Development Approach).

IJOTL TL (2019), 4(3): 173 186. DOI: 10.30957/ijot-ltl.v4i3.608.

The results of module validation on the aspect of content eligibility obtained an average of 32.33 validation results from a maximum score of 45 in the Good category. The score has been adjusted by expert input that validates the module. Scores obtained from 3 aspects of content eligibility include: (1) aspects of material coverage consists of 3 points, (2) aspects of material accuracy consist of 2 points, (3) aspects of relevance consist of 4 points.

The module validation results on the feasibility of the presentation obtained an average of 46 validation results from a maximum score of 65 in either category. Scores are obtained from 4 aspects of the feasibility of the presentation include: (1) the completeness of the presentation consists of 3 points, (2) the presentation of information consists of 4 points, (3) the presentation of learning consists of 5 points, (4) the update material consists of 1 point.

The results of the module validation on the feasibility of the language obtained an average of 13.5 validation results from a maximum score of 20 in either category. Scores obtained from 3 aspects of language eligibility include: (1) communicative consisting of 1 point, (2) Dialogical and interactive consisting of 2 points, (3) Conformity with Indonesian language rules consists of 1 point. Thus, the teaching material is worth testing out on a small scale.

\subsection{Revised Draft of Teaching Material}

The results of the module validation on the feasibility of the language obtained an average of 13.5 validation results from a maximum score of 20 in either category. Scores obtained from 3 aspects of language eligibility include: (1) communicative consisting of 1 point, (2) Dialogical and interactive consisting of 2 points, (3) Conformity with Indonesian language rules consists of 1 point. Thus, the teaching material is worth testing out on a small scale.

Based on the results of expert validation, the draft module for the Writing for Academic Purpose based on Blended Learning was then revised for later use in smallscale trials with the subject of 10 Semester VI PBI students in Lampung.

\subsection{Limited product testing}

After the module has been validated by an expert which is then revised, the next step is to be tested on a small scale by 10 assessors, namely students VI PBI UNU Lampung. The test is carried out by filling in the module assessment sheet (assessment instrument for students). The result of the assessment of the implementation of module by 10 students in the module limited trial. The average value obtained is 40.7 with a good category. Thus the teaching material is worth testing out through the e-learning system. 
IJOLT $\sim$ TL, Vol. 4, No. 3, September 2019

p ISSN: 2502 2326; e ISSN: 2502 8278

Https://soloclcs.org; Email: ijolt1@gmail.com

Center of Language and Cultural Studies, Surakarta, Indonesia

Sari, Purnama Maulita Eny \& Aini, Nurul. 2019. A Blended Learning Module on

the Writing Academic Purposes Course(A Research and Development Approach).

IJOTL TL (2019), 4(3): 173 186. DOI: 10.30957/ijot-ltl.v4i3.608.

\subsection{Evaluation Phase}

The next step is to evaluate the module products that have been produced and tested in class. This step is carried out to test the practicality and effectiveness of the modules used.

\section{a. Practicality Checking}

To obtain an evaluation of the practicality of this module, the researcher analyzes the interviews with students, and analyzes data obtained from the module's practicality evaluation sheet when used in class.

\section{b. Interview result}

Based on the results of interviews several students showed that; a) Easier to understand the material, b) Lectures are not boring, c) Students become aware of the learning process with the Blended Learning model, d) Academic writing is easier to understand, e) Students become independent, f) Blended Learning makes it easier for students to check work results.

\section{c. The Results Practical Evaluation Sheet}

The results of practicality evaluation data analysis were obtained by giving an evaluation to the observer in the learning process. The evaluation sheet was filled in for 4 meetings which were then conducted qualitatively. The results of practicality data analysis are as follows:

Based on the results of the analysis of the practicality of teaching materials during the four meetings as in table 5.4 above, obtained an average score of 26.5 from an ideal score of 30 or 88.33 with a very good category.

\section{CONCLUSION}

In this section, the researcher is going to begin by discussing the impact of DF on translation of idioms. Later on, the impact of IF on translation of idioms is going to be discussed.

Based on the explanation of the results and discussion, this research has several conclusions. The description is as follows:

1. The modules developed meet the criteria of validity, practicality and effectiveness.

2. The Writing for Academic Purpose module developed based on blended learning based on e-learning systems can improve students' reasoning and creativity skills effectively and significantly.

3. The profile of student learning activities towards the Writing for Academic Purpose Module which was developed based on blended learning assisted with an e-learning system categorized as excellent. 
IJOLT-TL, Vol. 4, No. 3, September 2019

p ISSN: 2502 2326; e ISSN: 2502 8278

Https://soloclcs.org; Email: ijolt1@gmail.com

Center of Language and Cultural Studies, Surakarta, Indonesia

Sari, Purnama Maulita Eny \& Aini, Nurul. 2019. A Blended Learning Module on

the Writing Academic Purposes Course(A Research and Development Approach).

IJOTL TL (2019), 4(3): 173 186. DOI: 10.30957/ijot-ltl.v4i3.608.

4. Teaching profile of lecturers on the Writing for Academic Purpose Module which was developed based on blended learning assisted by e-learning system in good category.

\section{ACKNOWLEDGMENTS}

The researcher would like to thank:

1. Mr. Nasir, S.Pd., M.Pd. as Chancellor of the University of Nahdlatul Ulama Lampung.

2. Mrs. Fitri April Yanti, S.Pd., M.Pd. as the Head of Lembaga Penelitian dan Pengambdiankepada Masyarakat (LPPM) UNU Lampung.

3. Mr. Miftahudin, S.Ag., M.Sc. as the Dean of the Faculty of Social Sciences and Humanities (FISH), Nahdlatul Ulama University, Lampung.

4. Mrs. Nurul Aini, S.Pd., M.Pd. as Head of the English Language Education Education Study Program University of Nahdlatul Ulama Lampung.

5. Mr. AgusKomarudin as the head of PUSKOM UNU Lampung.

6. And all parties that cannot be mentioned one by one.

\section{REFERENCES}

Daryanto. 2013. Menyusun Modul Bahan Ajar untukPersiapan Guru dalamMengajar. Yogyakarta: Gava Media

Drucker. P.F. 1999. Management Challenges for the 21st Century. New York: HarperCollins.

Garrison, D. R., \& Vaughan, N. D. (2008). Blended learning in higher education: Framework, principles, and guidelines. John Wiley \& Sons.

Kim, K. J., \& Bonk, C. J. (2006). The future of online teaching and learning in higher education. Educause quarterly, 29(4), 22-30.

Mosa, E. 2006. Puntoedu: a blended e-learning model. Current Developments in Technology-Asisted Education, 6(4), 1744-1749.

Mourtaga, K. (2010). Poor Writing in English: A Case of the Palestinian EFL Learners in Gaza Strip.

Powers.1997. $\quad$ Addie: Instructional Model (online). http://metalab.uniten.edu.my/ iskandar/project/july\%2009/ADDIE.pdf. Diakses pada 05 Maret 2019

Pramono. Y. B. H. 1996. Pembelajaranberbasiskomputerdalampokokbahasan present perfect tense matakuliah structure II pada program pendidikan Bahasa Inggris FKIP UniversitasWidya Mandala Surabaya. Tesis PPS IKIP Malang: Tidakterbit. 
IJOLT TL, Vol. 4, No. 3, September 2019

p ISSN: 2502 2326; e ISSN: 2502 8278

Https://soloclcs.org; Email: ijolt1@gmail.com

Center of Language and Cultural Studies, Surakarta, Indonesia

Sari, Purnama Maulita Eny \& Aini, Nurul. 2019. A Blended Learning Module on the Writing Academic Purposes Course(A Research and Development Approach). IJOTL TL (2019), 4(3): 173 186. DOI: 10.30957/ijot-ltl.v4i3.608.

Prastowo, Andi. 2011. Panduan KreatifMembuatBahan Ajar Inovatif. Yogyakarta: DIVA Press

Rahmana, A. Y, Susantini, E \&Yuliantini. 2015. ValiditasPerangkatPembelajaran Blended Learning. 04 (2), 848-853

Sudiman, A. S, R. Raharjo, A. Haryono, dan Rahardjito. 2010. Media Pendidikan, Pengertian, Pengembagan dan Pemanfaatannya. Jakarta; PT Raja GrafindoPersada

Sugiyono. 2007. MetodePenelitian Pendidikan (PenelitianKuantitatif, Kualitatif, dan R\&D). Bandung: Alfabeta.

Swail, W.S. 2002. Higher Education and the New Demographics: Questions for Policy. Change Magazine, 34, 15-23.

Syarif, Izudin. 2012. Pengaruh model blended learning terhadapmotivasi dan prestasibelajarsiswa SMK. Jurnal Pendidikan Vokasi, 2 (2), 234-249

Wijayanti, W. Maharta, N \&Suana, W. 2017. PengembanganPerangkat Blended Learning Berbasis Learning Management System Pada Materi Listrik Dinamis. JurnalIlmiah Pendidikan Fisika Al-BIRuNi, 06 (1), 1-12 
IJOLT-TL, Vol. 4, No. 3, September 2019

p ISSN: 2502 2326; e ISSN: 2502 8278

Https://soloclcs.org; Email: ijolt1@gmail.com

Center of Language and Cultural Studies, Surakarta, Indonesia

Sari, Purnama Maulita Eny \& Aini, Nurul. 2019. A Blended Learning Module on

the Writing Academic Purposes Course(A Research and Development Approach). IJOTL TL (2019), 4(3): 173 186. DOI: 10.30957/ijot-ltl.v4i3.608. 